\title{
Japan bids to widen brain research funds
}

[TOKYO] The Japanese government is to renew attempts to persuade other leading industrialized countries to increase their financial support for the Human Frontier Science Program (HFSP), the international research programme in molecular biology and brain science that was launched on Japan's initiative in 1987.

The issue of future funding will be a key item on the agenda of a meeting at the HFSP headquarters in Strasbourg on 24-25 March. The meeting has been called to agree on items to be discussed at an intergovernmental conference which is expected to take place in the United States later this year, perhaps to coincide with the G7 summit in Denver.

At the Strasbourg meeting - the first intergovernmental meeting on HFSP to be held for five years - Japanese officials hope to discuss the programme's funding 'inequality'; despite the success of the programme, Japan still pays for 80 per cent of its annual budget. The United States increased its contribution to the programme by $\$ 500,000$ to $\$ 4$ million last year. But most Western countries in the programme appear reluctant to increase their financial support.

The meeting comes at a critical time. The award rate for HFSP grants has fallen to 10 per cent, making it difficult for even highly regarded applications to win funding. HFSP officials are concerned that this may discourage good researchers from investing the time necessary to make applications in the future.

HFSP was started on the initiative of Yasuhiro Nakasone, the then Japanese prime minister, to pursue developments in the life sciences through international cooperation. At present, the United States and Canada jointly provide roughly 10 per cent of the programme's $\$ 45$ million annual budget. France, Germany, Italy, Switzerland, the United Kingdom and the European Commission together contribute a further 10 per cent.

\section{Task force will review US science policy}

[WASHINGTON] A bipartisan task force is to be set up in the House of Representatives to conduct a wide-ranging review of all aspects of US science policy.

The review, due for completion by the end of next year, will be led by Vernon Ehlers (Republican, Michigan), the vicechair of the Science committee and a former nuclear physicist. It has been set up after discussions with Newt Gingrich

(Republican, Georgia), the speaker of the House, and James Sensenbrenner (Republican, Wisconsin), the chair of the Science committee.

Ehlers said that both Gingrich and Sensenbrenner had "expressed an interest in a complete review of national science policy". According to congressional staff, Ehlers has obtained approval to pay for the salary of a staff director responsible for implementing the review. The review team is expected to hold hearings in the Congress, and to issue a report within the life of this Congress, which ends in December 1998.

Ehlers outlined his thinking during a meeting last Thursday (6 March) with the President's Council of Advisors on Science and Technology (PCAST). "We have to rethink the science policy of the nation," Ehlers told PCAST. "We don't have a science policy; we have a budget policy, and I want to correct that."

He pointed out that there had been several recent efforts by non-governmental groups - including a panel of the National Academy of Sciences chaired by its former president, Frank Press - to update the work of Vannevar Bush, whose 1945 report

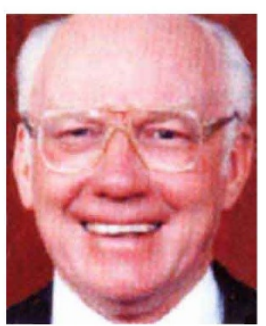

Ehlers: a physicist turned legislator.
Science: The Endless Frontier laid the foundations for US science policy after the Second World War. He welcomed these efforts but said that, "unless Congress and the administration buy into the process, it won't get anywhere".

Ehlers is a nuclear physicist who studied and lectured at the University of California at Berkeley before running the physics department at Calvin College, Grand Rapids, Michigan. He is particularly interested in undergraduate science education. But the scope of the review is expected to be far broader.

A similar review was undertaken in the mid-1980s by the then House science, space and technology committee, but it made slow progress and its staff was disbanded before a final report had been completed.

Veterans of that review suggest that the Ehlers initiative may fare better. They argue that restricted budgets mean that both government agencies and congressional committees are interested in receiving new guidance on setting priorities, which should lend impetus to the review process.

Together with the recent formation of a Science and Technology Caucus in the Senate, the review has been welcomed by science lobbyists in Washington, who see it as evidence of a resurgence of bipartisan support for science and technology in the Congress. Colin Macilwain
Principal investigators from the participating countries, who head multi-disciplinary international research groups, are entitled to compete equally for awards, regardless of the amount their country contributes.

At the previous intergovernmental conference, held in Tokyo in 1992, agreement was reached in principle on the desirability of achieving an equal match between the contributions of Japan and those of the other participating countries. But there has been only a slight increase in the share from other countries in the past five years.

HFSP grants are worth on average $\$ 240,000$ a year for up to three years, and 45 such grants were awarded in 1996. Of these, 38 per cent went to principal investigators in the United States, 15 per cent to Germany, 11 per cent to the United Kingdom, 13 per cent to France and 7 per cent to Japan.

In addition to the question of future funding, an agenda for the intergovernmental conference planned for later this year including possible new members, a change in the scope and activities of the programme, as well as various management issues, is expected to be finalized.

The meeting follows a review of the HFSP carried out by external consultants and published last year. This described the initiative as an "excellent and valuable programme", some of whose aspects are unique among science programmes, for example its encouragement of research collaboration at global level.

One participant is Terrence Sejnowski, a computational neurobiologist at the Salk Institute of Biological Studies in San Diego, California, who helped to organize a consortium to study the function and mechanisms underlying sleep with a grant from the programme. Sejnowski says that the programme has been "extraordinarily successful" in making possible research advances and publications.

But the HFSP continues to face the major hurdle that many of the participating countries consider that they can spend research funds more effectively through their national research organizations rather than through an international secretariat. Indeed, one British researcher, who previously won an award but has been unsuccessful in three recent applications, says he finds it easier to secure funds from funding organizations in the United Kingdom, despite its financial difficulties, and would oppose money being taken from the domestic budget and given to the HFSP.

After the meeting in Strasbourg, the programme's board of trustees will select the recipients of this year's grant and fellowship awards.
RichardNathan 